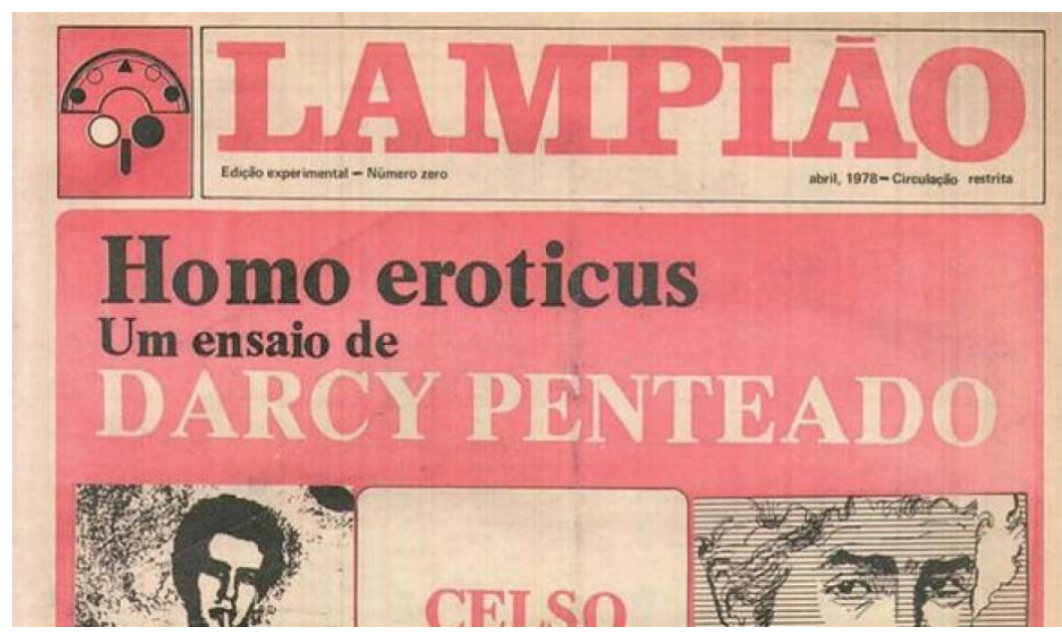

Vestígios do silêncio

Clues of silence

\author{
Iago Moura Melo dos Santos 1 \\ https://orcid.org/0000-0003-2144-0948 \\ Maurício Beck ${ }^{2}$ \\ https://orcid.org/0000-0002-8681-1626
}

\title{
Resumo:
}

Neste teatro textual, refletimos sobre o silêncio em três atos: 1. consideramos a significância do silêncio, a partir de Orlandi e em cotejo com outros autores; 2 . analisamos o editorial do Lampião da esquina, com o objetivo de compreender como o si dos sujeitos homossexuais é falado em relação ao gueto e como esse dizer constitui resistência à censura moral imposta pela língua-de-espuma da ditadura militar; 3. evocamos a significância do vestígio (trace) em Ricoeur e da ausculta em Heidegger, para especular sobre a escuta analítica em relação à temporalidade do silêncio. Para nós, o silêncio pode ser interpretado como a terceira margem do Rio Lethe (Ideologia), em relação à base material da língua (primeira margem), em que se dão os processos discursivos (segunda margem).

Palavras-chave: Discurso urbano; Censura; Gueto; Ausculta.

Abstract:

In this textual theater, we reflect on silence in three acts: 1 . we consider the significance of silence, starting from Orlandi and in comparison with other authors; 2 . we analyze the editorial of Lampião da esquina, to understand how the "self" of homosexual subjects is spoken in relation to the ghetto and how this saying constitutes resistance to moral censorship imposed by the frothy language of the military dictatorship; 3 . we evoke the significance of trace in Ricoeur and the auscultation in Heidegger, to speculate on analytical listening in relation to the temporality of silence. For us, silence can be interpreted as the third margin of Lethe River (Ideology), in relation to the material basis of the language (first margin), in which the discursive processes occur (second margin). Keywords: Urban speech; Censorship; Ghetto; Auscultation.

\footnotetext{
${ }^{1}$ Mestrando em Letras pelo Programa de Pós-graduação em Letras: Linguagens e Rpresentações (PPGLLR) da Universidade Estadual de Santa Cruz (UESC). E-mail: iagomouram@gmail.com.

${ }^{2}$ Professor e pesquisador no PPGLLR da UESC. Doutor e Mestre em Letras pelo PPGL da UFSM, com pós-doutorado no Programa de Pós-graduação em Estudos da Linguagem e no Laboratório Arquivos do Sujeito, da UFF. E-mail: pardalbeck@gmail.com.
} 


\section{No princípio não era o verbo}

No princípio era o Verbo, e o Verbo estava com Deus, e o Verbo era Deus. Ele estava no princípio com Deus. Todas as coisas foram feitas por ele, e sem ele nada do que foi feito se fez. João 1:1-3

Da morte de Deus, anunciada por Nietzsche, a Modernidade nos conduz à apoteose do homem como fundamento da palavra ${ }^{3}$. O Verbo genitor dá lugar ao performativo, ao Sujeito que manuseia a palavra como instrumento capaz de judicar sobre o mundo, modificar os gestos e agir livre (leia-se livre submissão ${ }^{4}$ ). Mas o fetiche do sujeito-centro cede espaço ao fetiche do centro-estrutura. $\mathrm{O}$ primado da subjetividade dá lugar ao seu recalque. Temos, então, ciência, signo, autonomia absoluta (língua/referente), significação diferencial e sistema de valor, epoché da história e do indivíduo $^{5}$. O Verbo se emancipa do homem e já não pode mais a tudo criar, exceto a si mesmo, pelo seu modo de ser específico, pela sua dobra. O significado aparece como imanente ao Significante, à revelia do "extralinguístico". São tempos de soberania do significante. É também a morte-do-Homem (Übermeschen) ${ }^{6}$ ?

De outra parte, somos conduzidos à falibilidade do Significante, enquanto imanência autossuficiente. Pela via da descontinuidade, chegamos, então, ao campo do discursivo, pelo que estranhamos a soberania da palavra com relação aos processos materiais que engendram o sentido, isto é, a história. Todo dizer, portanto, para que se produza, recorre à ordem do histórico, precisa haver-se com o já significado; parte (participa) do mnemônico do sentido. E os sujeitos respondem a essa injunção, constituídos enquanto tais pelo funcionamento da ideologia, que os submete à língua para dizê-los, circunscrevê-los à Identidade, à forma sujeito histórica que a todos nós recruta. Nesse campo, a metáfora, antes de havida enquanto figura, desvio ou mero ornamento, acidentais ou intencionais, é compreendida enquanto acontecimento do significante, cf.

\footnotetext{
${ }^{3}$ Estamos a nos apropriar aqui de parte da discussão proposta por Foucault (2001[1966]) em As palavras e as coisas, quando esse autor nos fala acerca da constituição da modernidade e das Ciências Humanas pelo aparecimento do homem enquanto duplo-empírico transcendental, fundamento da representação. A tese da morte de Deus, que ressoa em Foucault, advém de Nietzsche, que a articula enquanto fim da metafísica ou, ainda, num projeto de transvaloração de valores. Para Foucault, a episteme moderna articula a morte de Deus pela apoteose do homem, de modo que o aparecimento do homem como fundamento do conhecimento - cujo sintoma é o surgimento das Ciências Humanas - expressaria a continuidade da metafísica.

${ }^{4}$ É a Althusser (1980[1971]) que fazemos alusão, nesse ponto.

${ }^{5}$ Nada obstante haverem leituras no sentido de atribuir ao Saussure "diurno" (2012[1916]) o recalque da subjetividade $-v$. g. Indursky (2005) - é contra o fala "individual" que ele articula o corte de descontinuidade, no Curso de linguística geral.

${ }^{6}$ A morte do homem e o ser da linguagem seriam, para Foucault (2001[1966]), fenômenos correlatos. O autor está a retomar a reflexão nietzschiana a respeito do além-homem (Übermeschen) para intuir sobre o desaparecimento da episteme moderna.
} 
terminologia de Orlandi (2017), motor dos gestos de identificação, sendo o cerne da própria linguagem na constituição do sujeito e do sentido. Estamos nos domínios desdisciplinares da Semântica Discursiva ${ }^{7}$, formulada por Michel Pêcheux, na França, na segunda metade do século XX; retomada e alargada por Eni Orlandi, no Brasil. O modo corrente de nomear essa “disciplina de interpretação" é Análise Materialista de Discurso (doravante $\mathrm{AD})^{8}$, pelo que se faz eco ao caráter material do sentido, sua inscrição na ordem do histórico pelo ideológico; o discurso como materialidade específica da ideologia; a língua enquanto materialidade específica do discurso; o dizer como efeito de um processo já gestado em outro lugar e independentemente etc. Os sujeitos observados não são "empíricos", mas lidos enquanto posições no discurso, alinhadas a dadas formações ideológicas em que se intrincam formações discursivas determinadas, tomadas em sua provisoriedade metafórica e não-identidade consigo mesmas, isto é, enquanto verdadeiras máquinas paradoxais. O sujeito é não-um, clivado, afetado pelo inconsciente. Não são mais tempos de sujeito livre, mas de "livre" assujeitamento.

Neste teatro textual, recorremos à $\mathrm{AD}$ para sitiar o silêncio, havido enquanto real não-homogêneo do discurso, pelo que convocamos, principalmente, os estudos de Eni Orlandi (1997[1992], 1999, 2017). O domínio significante do silêncio constitui importante suplemento aos estudos do discurso (por que não dizer, da linguagem?), notadamente por permitir encarar a incompletude do linguístico, sua saturação, desde onde se abre um novo modo de olhar para as diferentes materialidades discursivas que se cruzam; circunscrever a censura constitutiva que atua na não-presença que garante todo dizer, bem como compreender melhor os efeitos da censura que arruína a cena do dizível em formulação, numa dada conjuntura sócio-histórica. A língua é a base material (primeira margem) dos processos discursivos (segunda margem). Havemos o silêncio, portanto, como a terceira margem da significação, o lugar do não-Um, do impossível que se faz possibilidade pela língua ${ }^{9}$. Parodiando o discurso bíblico, nos propomos a compreender a fundação do semântico menos na face imediata do Verbo-estrutura do que em seu avesso. No princípio era o silêncio. Mas o silêncio significa, seja encarnado num corpo ou fora dele. O seu modo de fazer sentido é específico: o silêncio é e, é desde esse

\footnotetext{
${ }^{7}$ Em A semântica e o corte saussuriano: língua, linguagem, discurso, é sob o rótulo "semântica discursiva" que Haroche, Pêcheux e Henry (2007[1971]) designam a teoria do discurso fundada na França da segunda metade do século XX, tendo Pêcheux como precursor.

8 Sobre o caráter interpretativo da AD, v. Pêcheux (2015[1983]), em O Discurso: estrutura ou acontecimento?

${ }^{9}$ Esse gesto de interpretação que fazemos a respeito das margens do Rio Ideológico será melhor precisado adiante, no terceiro ato.
} 
modo de ser, ele se volta para nós, atravessa os discursos, divide sentidos pelo político, transpõe fronteiras e cria outras. Há limites para os sentidos, mas há também limites construídos com sentidos (ORLANDI, 1999). Isso, para nós, constitui um efeito de leitura da máxima de Michel Pêcheux (1997[1969]): a linguagem serve para comunicar e para não comunicar. Vamos nos deter, neste trabalho, nesse último aspecto do funcionamento da linguagem - sua relação com o não dizer - pelo que a contrapomos à cena do silêncio tomado em sua significância material. O mais importante não é da ordem do dito, mas do não-dito, ou, como quer Orlandi (2017, p. 10), “[...] a parte voltada ao silêncio é, sempre, em qualquer conjuntura histórico-social, mais importante do que o que se diz.". Não olvidamos, contudo, que, além da "aposta" comunicativa e do caráter não-comunicativo da linguagem, essa serve também ao escopo de significar e, frisamos, assujeitar, antes de tudo.

Estar no silêncio corresponde a um modo de estar no sentido (ORLANDI, 1997[1992], p. 12). Embora o silêncio tenha sido relegado a uma posição secundária, enquanto resto de linguagem, pela tradição epistêmica ocidentalocêntrica, Orlandi insiste que "[...] o sentido do silêncio não é algo juntado, sobreposto pela intenção do locutor: há um sentido no silêncio [..]", isto é, o silêncio é significante em si. Se todo dizer se constitui a partir de uma relação fundamental com o não dizer, cumpre constatar que também o não-dizer se liga à história e à ideologia. O silêncio, então, comparece como fôlego da significação, lugar de recuo diferencial, necessário para que o sentido faça sentido, de onde se pode inferir que o "fora" da linguagem é também já sentido, compõese de uma materialidade simbólica específica ${ }^{10}$. Há, assim, uma dimensão do não-dito absolutamente distinta do que a semântica argumentativa, v.g. Ducrot, tem denominado “implícito", de que esse último aparece apenas como efeito ${ }^{11}$.

O tempo do silêncio (aevum) é contínuo, enquanto que o tempo da palavra (tempus) é marcado. A palavra marca e segmenta o silêncio, constituindo um tempus no

\footnotetext{
${ }^{10}$ Conforme Orlandi (1997[1992]), o silêncio é o "fora" da linguagem, o que faz com que a autora divirja das posturas integracionistas, v.g. Barthes, para quem o silêncio é também linguagem.

${ }^{11}$ Cf. Orlandi (1997[1992]), o implícito é já um subproduto, isto é, um efeito, do trabalho do silêncio. Se o implícito remete ao dito, isto não ocorre com o silêncio constitutivamente considerado, o qual permanece silêncio, mantém-se como tal. Em suma, não reduzimos o não-dito ao implícito. Restituímos a ele a sua referência em si, o seu caráter independente, o seu sentido mesmo que é o de ser-velado. Ducrot (1977), de outra parte, trabalha a implicitação sob duas formas, pelas quais contesta o caráter estritamente comunicacional da linguagem, havendo a significação pelo dito e pelo não dito que the subjaz significado. São elas: a) subentendido - significação atestada pelo próprio dizer que escapa à intenção de comunicar; b) pressuposto - que diz, como se não dissesse, apresentando-se em virtude da significação das frases da língua. Nesse sentido, v. especificamente o capítulo "Implícito e pressuposição". Ver também Guimarães (2015).
} 
contínuo dos sentidos (aevum). A linguagem é lugar de estabilização dos sentidos e dos sujeitos, enquanto que, no silêncio, aqueles se movem largamente. Cumpre, portanto, salientar a diferença ontológica (material) e de funcionamento entre silêncio e linguagem, pelo que resulta inoportuno traduzir o não-dizer em palavras, sob a injunção do Império do Verbal que governa o fazer epistêmico do Ocidente, a não ser pela via de seu funcionamento (como cala? Como apaga? Como interdita? Como censura? Como constitui? Quais efeitos produz?). O silêncio é matéria significante distinta da linguagem. O significar não tem exterior. A linguagem, tomada em sua incompletude e referida ao silêncio, produz-se, ao revés, sob o efeito de separação entre "exterior" e "interior". Linguagem é excesso, saturação de sentido. O silêncio não é falta, contudo. O silêncio é. Ser estruturante pelo avesso é o que caracteriza seu modo de ser.

A linguagem divide, administra e categoriza o silêncio, de modo a tornar a significação calculável. O silêncio, contudo, passa pelas palavras; é mediatamente visível, efêmero, escorre, é fugaz. "O silêncio não é transparente e ele atua na passagem (des-vão) entre pensamento-palavra-e-coisa." (ORLANDI, 1997[1992], p. 39). A linguagem transforma essa matéria significante, dá-lhe corporeidade verbalizável, significação específica. A ideologia da comunicação trabalha na subalternização do silêncio, em seu apagamento. $\mathrm{O}$ silêncio, portanto, em nossa tomada de posição, não significa à revelia de determinações; ele é pressurizado pela cultura, pelo trabalho, pela história, pelo político. Pensar o silêncio é um esforço contra a hegemonia do formalismo, contra o positivismo na observação dos fatos de linguagem; implica problematizar as noções de linearidade, literalidade e completude; impõe colocar questões a propósito da dialogia, da relação com o Outro, de que o silêncio é limite; exige problematizar palavras como representação, interpretação; demanda resistir à redução da significância à linguagem verbal. Para compreendê-lo, em sua opacidade material, cumpre torná-lo "visível” em seu funcionamento, isto é, observável indiretamente, pela administração de métodos discursivos, históricos, críticos, desconstrutivistas. O silêncio só é apreensível pelos seus efeitos, pelos muitos modos que constitui a significação. Mostra-se por fissuras, falhas, rupturas. Ele não se anuncia por marcas formais, isto é, pegadas de uma presença que passou, mas a partir de pistas, traços; como estamos a propor neste trabalho: a partir de vestígios (traces) significantes ${ }^{12}$.

\footnotetext{
${ }^{12}$ No terceiro ato, pretendemos elaborar mais detidamente a aproximação entre silêncio e vestígio a que nos propomos.
} 
Orlandi (1997[1992], p. 60), atenta ao fato de que é “[...] a historicidade inscrita no tecido textual que pode 'dissolvê-lo' [o silêncio], torná-lo apreensível, compreensível [...]", propõe três modos de aproximação, a saber: a) trabalhar com a noção de completude/incompletude; b) analisar as figuras deslocando e relendo elementos de análise da Retórica; c) relacionar múltiplos textos (intertextualidade), por análises parafrásticas, em particular"13.

Em AD, o imaginário é condição do significar, do sujeito e do sentido. Ele convoca a "forma unitária" (PÊCHEUX, 2014[1975]), isto é, o Um, a Realidade, a Identidade. Todavia, há real (que, conforme a psicanálise lacaniana, não se confunde com realidade), embora se possam nele supor regiões heterogêneas. O silêncio, então, materializa-se na relação entre real e imaginário, anunciando a sua opacidade e seu papel semântico, seu modo de ser na divisão do trabalho do sentido. O real, o simbólico e o imaginário - incluindo aí o silêncio tal como ele (re)escreve essa relação triádica articulam-se pela (sobre)determinação histórica, pelo funcionamento da ideologia na língua, e não sob o primado analítico do inconsciente ${ }^{14}$.

Dizer que o papel do silêncio no semântico é de fundador, não implica concebêlo enquanto originário, ou lugar de habitação de um sentido absoluto, preexistente, autossuficiente. Ao revés, trata-se de haver o silêncio enquanto garantia do movimento de sentidos, “[...] a possibilidade para o sujeito de trabalhar sua contradição constitutiva, a que o situa na relação do ‘um' com o ‘múltiplo' [...].” (ORLANDI, 1997[1992], p. 23). É ele, o silêncio fundador, que nos forja a possibilidade de significar, transitar do semsentido ao sentido (ORLANDI, 2017). A partir do que nos diz Foucault (2017[1976], p. 31), no sentido de que “[...] não existe um só, mas muitos silêncios e são parte integrante das estratégias que apoiam e atravessam os discursos [...]", podemos, então, insistir, ainda na esteira de Orlandi (1997[1992], 2017), na distinção entre diferentes formas do silêncio significar, a saber: a) silêncio fundador - aquele que existe nas palavras, significa no nãodito e dá espaço de recuo significante como condição para a significância do dito, em que há margem para um interlocutor em silêncio; b) política de silêncio (silenciamento) - em que constitui-se um interlocutor silenciado - a qual se subdivide em b.1) silêncio

\footnotetext{
${ }^{13}$ A esse conjunto analítico, imprimimos a consideração dos vestígios significantes, pela via da filosofia da história, para aprimoramento de um dispositivo a que chamaremos de dispositivo de "ausculta. Igualmente, no terceiro ato, traremos o conceito de ausculta em cotejo com os estudos do silêncio e a problemática do vestígio.

${ }^{14}$ A ressalva que é feita sobre a categoria de análise "inconsciente" deriva do fato de que, apesar de a AD se constituir a partir da solidariedade epistemológica entre o Materialismo Histórico, a Psicanálise e a Linguística, o seu ponto de destaque reside na observação da relação entre língua e ideologia.
} 
constitutivo, de onde se infere que para dizer é preciso não dizer; b.2) silêncio local (ou censura), isto é, a coerção que se fecha ao possível e ao dizível, de modo a estabelecer o proibido de se dizer numa conjuntura sócio-histórica dada.

O silêncio constitutivo trabalha na (re)produção do sujeito, de sua identidade, e do sentido; configura assimetrias, impossíveis. A ideologia funciona pela interpelação (ALTHUSSER, 1980 [1971]), pelo que são recrutados, entre os indivíduos (todos nós), sujeitos constituídos "à semelhança" da Identidade, do Sujeito. O silêncio em questão opera no "se" da identidade, refrata o impessoal, o "todo mundo", pelo que, no interlocutor, recua o seu "si", isto é, o real de sua existência. A forma constitutiva do silêncio atua na subsunção que se opera entre sujeito/Sujeito, configurando a falha no ritual, lugar de hiância. Da parte do sentido, o silêncio constitutivo atravessa o vértice (interdiscurso) do dizer e seu horizonte (intradiscurso), fazendo com que as formações discursivas que daquele se recortam possuam lugares de impossibilidade, bem como sejam sempre fronteiras em deslocamento, perpetuamente diferentes de si mesmas. Mas como pode o silêncio constituir? Pelo corte do interdito, de que nos fala Tfouni (2016). Ratificando a distinção entre silêncio constitutivo (espécie de política de silêncio) e silêncio fundante, conforme Orlandi (1997[1992]), compreendemos que é pelo interdito que o dizer silencia, constitutivamente e pela censura. Essa dimensão do silêncio engendra-se pelo trabalho (BECK, 2016), de que o interdito é um operador fundante e possui primazia - já que admitir que o interdito teria primazia sobre todo o silêncio, incluindo aí o fundante teria por consequência reduzir o real do discurso à linguagem pela tomada do fundante como constitutivo. Posta a primazia do real ante à palavra é que pensamos que a linguagem não pode trabalhar o real, a não ser por alusão. O linguístico dá conta do imaginário, mas o real escapa. A essa região do real, o real do discurso notadamente, chamamos silêncio fundante. O fundante "aparece" quando o caos contamina a ordem, quando a linguagem não faz sentido-Um, mas babeliza-se. É aí que o fundante se torna possibilidade analítica, faz vestígio (trace).

É ele, o silêncio fundante, que garante o silêncio-de-si, como forma artificiosa de não dizer, pelo corte do interdito que já lhe é ulterior. É como lemos a seguinte formulação de Tfouni (2016, p. 88): “[...] o que cria tanto o silêncio quanto o discurso é uma interdição, que é uma operação linguística: é a entrada da linguagem que cria tanto o discurso quanto o silêncio.". Tomando partido de que o real do discurso não é o interdito, mas o silêncio fundante, cf. Lisboa (2016), pensamos ser a interdição constitutiva. Mas o silêncio fundador nada constitui, pois ele é. O silêncio fundante é, pensamos, um modo 
de compreender aquilo que é Ser, tal como Heidegger (2012[1927]) o interpreta na clareira da diferença ontológica ser-ente ${ }^{15}$. O interdito, ao revés, aloja-se num real que já é, como um de seus subprodutos. É que o inter-dito está dito no meio, de modo que não se confunde com o não dito. Ele é o silenciado - mas não o silêncio em si -, é o "rejeitado" de que nos falam Pêcheux e Fuchs (1993[1975], p. 176)

Diremos que os processos de enunciação consistem em uma série de determinações sucessivas pelas quais o enunciado se constitui pouco a pouco e que têm por característica colocar o "dito" e em consequência rejeitar o "não-dito". A enunciação equivale, pois a colocar fronteiras entre o que é "selecionado" e tornado preciso aos poucos (através do que se constitui o "universo do discurso"), e o que é rejeitado.

De outra monta, o silêncio local (censura) arruína o possível da formulação. Nesse caso, o próprio "se" é corroído e quase não há espaço diferencial para o "si": “[...] com a censura há negação da alteridade mas também a identidade é aniquilada." (ORLANDI, 1997[1992], p. 82). Uma vez recortadas do vértice do dizer, as diferentes formações discursivas constituem-se enquanto lugares provisórios daquilo que pode e deve ser dito de uma dada posição ideológica (HAROCHE; PÊCHEUX; HENRY, 2007 [1971]). Entretanto, a formulação pode ser mais ou menos vigiada, a depender do estado em que se passa uma dada formação social. Em sede de censura, têm lugar aquilo que Burke $(1999$, p. 2) denomina como “[ [...] leis do silêncio, que tratam daquilo que não é permitido dizer: quando, onde, por quem, a quem e também, com certeza, sobre o quê - em outras palavras, as leis dos temas proibidos.". Trata-se da interdição; dos efeitos de "foraclusão" de sentidos possíveis, mas não queridos, que constituem um sujeito em disritmia no dizer (ORLANDI, 2017) pela hipernomia do não, afetado em suas possibilidades de (se) significar.

Ainda na cena da formulação, como essa ocorre na enunciação, o silêncio pode "aparecer" como vestígio sintomal. Ao dizermos isso, pensamos nos estudos da linguista Authier-Revuz (2010[1994]). A autora explora o silêncio no dizer como sintoma da contradição entre palavra e coisa, em eventos de nomeação. O silêncio aqui não diz respeito apenas ao não dizer, mas a como, pelo dizer, os sujeitos administram, através de laços metaenunciativos, a falta do dizer, pelo dizer da falta. Havendo-se com o silêncio,

15 "Man sagt: 'Sein' ist der allgemeinste und leerst Begriff. Alls solcher widerstht er jedem Definitionsversuch. Dieses allgemeinst und daher undefinierbare Begriff bedarf auch keener Definition. Jeder gebraucht ihn ständig und versteht auch achon, was er je damit meint." (HEIDEGGER, 2012[1927], p. 33). O Ser, assim, é nele mesmo: insuscetível de definição e perpétuo retraimento de si; ele é silêncio que significa. 
os sujeitos retornam ao dito "[...] reflexivamente sobre um ponto de seu desenvolvimento, para no tempo deste 'laço' [...] suspender o 'que vai por si mesmo' sob o modo pelo qual parece dar-se normalmente a nomeação, inscrevendo nela explicitamente a falta.” (p. 255). É assim que, para a autora, “[...] as línguas imaginárias ou o silêncio respondem pela apresentação fictícia, de um lugar outro, à ferida da linguagem [...].” (AUTHIERREVUZ, 2010[1994], p. 254).

Arrematemos. O silêncio fundante é multiplicidade de sentidos em movimento centrífugo, pois nele sujeito e sentido se movem largamente. As formas políticas do silêncio, todavia, significam (n)o dito, acompanham a linguagem como o velado em tudo o que aparece, já que o modo de ser do logos é, como nos diz Fogel (2017), aparecer, mostrar - leia-se mostrar enquanto evidenciar, posta a eficácia do imaginário. Ausências que determinam presenças. Ele, o silêncio fundante, entretanto, não remete ao dito, mas é a própria remissão, o impossível, o real do discurso. O silêncio fundante é o avesso do Verbo. É essa a forma do silêncio que abre recurso ao "si", embaralha o ritual, descontinua o "se" em referência à Identidade. De outro lado, pelo silêncio constitutivo há o silêncio do "si" pelo "se"; pelo silêncio local há quase a aniquilação do "se" e uma tentativa de apagar vez por todas o "si" - o real da existência do indivíduo, pelo limite da interpelação. Podemos, agora, dizer que é por que há silêncio fundante que há modos de calar que correspondem ao que chamaremos de "silêncio-de-si", como recusa à Identidade, pelo que se imprimem pontos de (r)e(k)sistência no iter ideológico. Aqui, o silêncio obstrui a injunção fascista, diria Barthes (1978), a dizer ${ }^{16}$. É no silêncio-de-si que tem lugar os efeitos políticos, corrosivos e subversivos, do calar, de que nos fala Beck (2010, 2013, 2016), enquanto gestos de afasia/apraxia - não agir, ao modo de uma prática desgastada; não falar, enquanto resposta negativa ao poder; antipredicativa. Seria esse o espaço possível do governo de si? ${ }^{17}$ Como nos diz Freud, é o homem dono do que cala, mas escravo do que diz.

\footnotetext{
${ }^{16}$ Aqui, aludimos a Heidegger (2005[1947]) para distinguir o "se" (o "on", no francês, o "das Man", no alemão; o "a gente", no português) do "si", enquanto "poder" ser si mesmo, bem como para apreender o sentido de existência enquanto existir fora, isto é, ek-sistir. O "silêncio-de-si" tem ares do "cuidado-de-si", pensamos, a partir de Foucault (2017[1984]), cotejando-o com Pêcheux (2015[1984]), que conclama ao "pensar por si mesmo" - embora essa aproximação ainda exija pesquisas mais aprofundadas. Se há modos de calar que são da ordem do "se" (interlocutor silenciado), concebemos que há modos de "calar-por-simesmo", em que tem lugar a figura do interlocutor em silêncio, pelo ousar silenciar.

${ }^{17}$ É evidente que uma tal questão extrapola os limites deste trabalho. Adiamos a compreensão de suas consequências teórico-analíticas para trabalhos ulteriores, em que nos proporemos a analisar como que, a partir do silêncio-de-si, resiste-se à interpelação ideológica, pelo que a identificação pode não fazer Identidade e os sentidos podem não fazer literalidade e univocidade.
} 
Nosso objetivo analítico, neste teatro textual, reside em compreender os efeitos do silêncio local no discursivo, enquanto materialidade específica da ideologia. Para tanto, trazemos alguns gestos de análise, no segundo ato, a respeito da divisão de sentidos que se engendra a partir da produção de um discurso sobre o silenciamento (gueto) e sobre o sujeito homossexual, no editorial da edição experimental (1978), do jornal guei ${ }^{18}$ Lampião da esquina, tomado enquanto discurso urbano. Procuramos vestígios de resistência, tomando a censura, que funcionou no regime militar, como locus de observação. De outra parte, nosso objetivo teórico-conceitual consiste em melhor compreender a escuta analítica, tendo em conta a significação peculiar do não dizer, a partir de uma tomada de posição especulativa sobre a temporalidade do silêncio. Para isso, no terceiro ato, recorremos a Paul Ricoeur, para evocar a significância do vestígio (trace), e a Martin Heidegger, para propor o conceito de ausculta, em sua produtividade para o estudo do silêncio. Situamos o modo de significar do silêncio como terceira margem do Rio Lethe (Ideologia), em relação à base material da língua (primeira margem), em que se dão os processos discursivos (segunda margem). Especulamos ser oportuna, como um possível caminho analítico, a construção de uma "ausculta" atenta à materialidade significante do silêncio, em sua especificidade, que se faça alternar com a escuta discursiva, na forma de um batimento.

\section{Uma imagem do silêncio: o gueto homossexual}

A placa de censura no meu rosto diz: Não recomendado à sociedade Caio Prado

Apresentamos, neste segundo ato, alguns enunciados recortados ${ }^{19}$ do editorial da edição teste do Jornal guei Lampião da esquina, datada de 1978, para pensar a significância do gueto como uma imagem do silêncio local. Trata-se do gueto homossexual como lugar a que as sexualidades "heréticas", cf. terminologia de Foucault (2017[1976]), estariam supostamente aniquiladas pelo discurso. Cumpre ressaltar que o aludido jornal é tomado aqui enquanto um veículo do discurso urbano, uma vez que

\footnotetext{
${ }^{18}$ Neste trabalho, empregaremos o termo guei, tal como no Lampião.

19 Subscrevemos a concepção de Orlandi (1984), para quem o texto é um todo em que os recortes se organizam. Acompanho, assim, a passagem da segmentação, operação que visa a relação entre as unidades dispostas linearmente e mecanicamente hierarquizadas e que compreende o segmento como unidade ou da frase do ou do sintagma; para o recorte, que não concebe uma passagem automática entre as unidades discursivas e o todo que por elas é constituído. "O recorte é uma unidade discursiva. Por unidade discursiva entendemos fragmentos correlacionados de linguagem-e-situação. Assim, um recorte é um fragmento da situação discursiva." (p. 14).
} 
produziu um falar sobre o confronto entre o simbólico e o político na cidade $^{20}$. Procuramos, então, observar de que maneira os sujeitos do discurso, a medida em que são afetados pela censura moral, reescrituram a imagem do gueto pelo discurso sobre (MARIANI, 1996) o silenciamento e sobre o seu si.

O jornal Lampião da esquina ${ }^{21}$ surge no início da suposta abertura política da ditadura militar, em 1978 (governo do General Ernesto Geisel), a partir da entrevista com Winston Leyland - editor do Gay Sunshine, tabloide americano dirigido ao público homossexual - feita por João Antônio Mascarenhas, à época colunista do Pasquim ${ }^{22}$. Leyland estava no Brasil para organizar uma antologia de literatura guei latino-americana. Mascarenhas e o grupo de convidados que acompanharam a entrevista ficaram empolgados com o relato de Leyland sobre o Gay Sunshine, a ponto de decidirem lançar um periódico que abordasse o homossexual "de forma séria". Após a entrevista, o grupo se reuniu na casa do artista plástico e escritor Darcy Penteado, em São Paulo, encontro que marcou o início do projeto Lampião. Dentre os criadores do jornal, podemos citar: Adão Costa, Aguinaldo Silva, Antônio Chrysóstomo, Clóvis Marques, Darcy Penteado, Francisco Bittencourt, Gasparino Damata, Jean Claude Bernardet, João Antônio Mascarenhas, João Silvério Trevisan e Peter Fry; os quais passaram a integrar o Conselho Editorial do periódico.

O jornal teve periodicidade mensal e tiragem entre 10 e 20 mil. Circularam 37 edições oficiais, entre 1978 a 1981, além de três edições extras e da edição experimental, cujo editorial constitui o objeto de análise deste trabalho ${ }^{23}$. Cumpre mencionar que a edição experimental (1978) circulou de modo não tradicional, seja porque teve um plano de divulgação preparado muito rapidamente, seja em razão das condições de censura moral a que estavam submetidas as comunicações e mídias, sobretudo aquelas que

\footnotetext{
${ }^{20}$ Sobre o conceito de discurso urbano, v. Orlandi (1999).

21 "Um aspecto importante do jornal está em seu nome, que a princípio nos remete ao cangaceiro Virgulino Ferreira da Silva, conhecido como Lampião, mas essa nomenclatura não possui relação com o cangaço e pode ser compreendida como um interessante marketing, por ser um jornal de viado com nome de cangaceiro. Todas as edições do jornal trazem um símbolo que remete a Virgulino, um chapéu de cangaceiro, porém, a outra parte do desenho que forma os óculos e o nariz, é uma referência a um pênis" (BRITO, 2016, p. 20).

${ }^{22}$ Vale ressaltar que o Lampião surge como reação ao Pasquim, que, embora constituísse importante jornal alternativo, mostrava-se insensível em relação às questões das ditas minorias e endossava as práticas de censura moral da ditadura militar. O Pasquim (1960-1961) rearranjou a discursividade jornalística brasileira, apresentando, como novidades: um humor subversivo, bastantes ironias e ilustrações, textos curtos e frases de alta polissemia, além de estabelecer a coloquialidade na mídia. Entretanto, com a relação aos gueis, ele se comportava como a grande imprensa, reforçando estigmas e reproduzindo o discurso de censura moral. V. MacRae (1990).

${ }^{23}$ Sobre o quadro para-textual do Lampião, v. Simões Júnior (2006).
} 
visibilizavam as notações culturais de cunho homossexual. Isso porque a circulação da edição teste se restringiu à comunidade guei brasileira, principalmente no eixo Rio-São Paulo, tendo sido enviada para leitores específicos via malote postal. Citamos o fato de a edição teste, bem como a edição um, terem sido objeto de censura moral, inclusive, pelas instituições repressivas da ditadura, como o DOPS/SR/DPF/RJ (Delegacia de Ordem Política e Social), que instaurou o inquérito $\mathrm{n}^{\circ}$ 25/78 para identificar e punir os responsáveis pelo flagrante atentado aos preconceitos da moral e dos bons costumes, que estaria supostamente consignado nas páginas das primeiras edições do tabloide ${ }^{24}$. As edições posteriores, entretanto, tiveram divulgação oficial, com circulação em bancas de revista do eixo Rio/São Paulo e demais estados da federação.

De acordo com Quinalha (2017), embora, em 1978 se dê o início da dita abertura política, "lenta, gradual e segura", é também o momento de intensificação das práticas de controle moral e, portanto, de práticas discursivas de funcionamento censório aos sentidos e sujeitos moralmente subversivos. A classe de latifundiários, a Igreja e a classe empresarial clamavam pela preservação dos ideais conservadores, não satisfeitos com a proposta de redemocratização. Isso orientou as práticas simbólicas no sentido de se intensificar os procedimentos de controle moral e modalizou o possível do dizer em suas condições de produção sociais e históricas. A despeito da promessa de novos ares pelo incipiente processo de redemocratização, a censura moral e a perseguição institucionalizada a homossexuais seguiam firmes, além do fato de as instituições censórias terem permanecido até a Constituição de 1988. Os sentidos moralmente subversivos, assim, não passavam livremente, sendo cooptados pela língua-de-espuma ${ }^{25}$, que deixa de tentar conter o estritamente político para conter "o político" no moralmente subversivo. Sentidos politicamente subversivos, pelo menos de um prisma estritamente político, tornam-se formuláveis ou alvo da autocensura; enquanto que sentidos moralmente subversivos foram interditados. A ditadura permaneceu: na moral e nos costumes.

A conjuntura sócio-histórica do final dos anos setenta é legatária de sedimentações discursivas que remetem mesmo a antes do golpe militar de 1964. Cruzaram-se os fios do

\footnotetext{
${ }^{24}$ Para uma discussão mais detalhada sobre o Inquérito no $25 / 78$, v. Quinalha (2017).

${ }^{25}$ Cf. Orlandi (1997[1992]), a língua-de-espuma era a língua falada pelos militares na ditadura brasileira. Tratava-se de uma língua "vazia", prática, de uso imediato, em que os sentidos não ecoavam. Por efeito dessa língua, trabalha-se o poder de silenciar. Entendendo a viragem no possível do dizer que se dá com a dita abertura democrática do regime, compreendemos que ao passo que sentidos estritamente políticos de cunho antagônico ao regime tornaram-se formuláveis, os sentidos moralmente subversivos tornaram-se cada vez mais silenciados.
} 
discurso médico-psiquiátrico, dos discursos integralistas e dos moralismos atinentes ao discurso cristão. O sentido de homossexual foi trabalhado, então, no jogo com a historicidade do interdiscurso, como patologia; risco ao desenvolvimento e progresso do Estado enquanto nação; ameaça comunista; risco à família tradicional: degenerescência econômica, moral, política, biológica, isto é, matéria de silenciamento. O autoritarismo de Estado, referendado pelo funcionamento conjugado dos aparelhos ideológicos de Estado, cf. terminologia de Althusser (1980[1971]), "família" e "igreja", condicionou, assim, a significância dos sujeitos homossexuais pelo silêncio, afetando as formações imaginárias que os encampavam e naturalizando, pelo funcionamento da ideologia, a sua imagem como inimigo do contrato social, do Leviatã.

Entendemos, cf. Fico (2015), que, na ditadura militar brasileira, duas dimensões se entrecortavam. Uma dimensão saneadora, escudada no imaginário da necessidade de extermínio de comunistas e terroristas, enquanto ameaça política ao regime; e uma dimensão pedagógica, que trabalhava os procedimentos de controle das práticas simbólicas, pelo caráter dito suscetível da juventude brasileira, já que essa estaria supostamente a mercê das influências negativas do movimento comunista internacional. A dimensão pedagógica visava, assim, a um controle moral, cujo objetivo era o de preservar, sobretudo, a juventude, a partir do silenciamento das notações culturais que remetessem à liberação dos costumes, operando pela produção de estigmas. Essas duas dimensões podem ser pensadas como aspectos da língua-de-espuma falada pelos militares, ressalvando-se que, é na dimensão pedagógica que se visavam conter os sentidos subversivos de homossexual e suas práticas de identificação/subjetivação, sobretudo, em tempos que a ditadura moral e dos costumes se tornou mais visível com a dita abertura política. Sob o pretexto de uma abertura "lenta, gradual e segura" tentou-se conter, pelo silêncio, o direito ao prazer e ao orgasmo "amplo, geral e irrestrito" 26 .

Para Cowan (2015), a censura moral aparece como uma forma de justificar a perpetuação do regime, uma vez que o risco político teria aparentemente sido minado pelas políticas repressivas de combate aos grupos de luta armada, de que a ditadura lançou mão. Nas palavras do aludido autor,

[...] diante da ausência da resistência armada, que foi dizimada no começo dos anos 1970; viram-se com quase pânico aos vínculos entre ativistas dos movimentos gay, feminista, negro e outros, vendo neles a

\footnotetext{
${ }^{26}$ Sobre o sentido da expressão "orgasmo 'amplo, geral e irrestrito"” em relação ao da abertura política, v. Quinalha (2017).
} 
confirmação do que a linha-dura sempre suspeitou: que estas minorias fossem componentes de um todo, culturalmente subversivo, que tendia a promover os interesses dos comunistas (COWAN, 2015, p. 42).

Ratificando os estudos de Orlandi (1997[1992]) sobre o funcionamento da censura na ditadura militar brasileira, enfatizamos: não há, como não houve no aludido período, censura sem resistência. Embora a censura já tivesse se instalado no cotidiano de todo brasileiro, pelo que "[...] cada um experimentava, na sua própria intimidade, os limites do dizer [...]" (ORLANDI, 1997[1992], p. 114), isso não impediu que se estabelecessem formas muito variadas de comunicação e de resistência, de que é exemplo o Lampião da esquina, jornal que constituiu "sítio de significância", a partir da formulação e divulgação de discursos sobre a censura moral a que estariam submetidos os sujeitos homossexuais; veículo de discurso urbano, uma vez que produziu um falar sobre o confronto entre o simbólico e o político na cidade Os sentidos moralmente proibidos, de alguma maneira, significavam, encontrando modos de transpirar, de responder à censura. Os sentidos censurados não desaparecem simplesmente, pois "[...] ficam seus vestígios de discursos em suspenso [...]." (ORLANDI, 1999, p. 71). No Lampião, então, a imagem do "gueto" aparece como vestígio (trace) sintomal dos silêncios sobre a identidade do sujeito homossexual, que atuavam pelo funcionamento censório da língua totalitária do regime militar. O tabloide circulou um discurso sobre a censura moral que constituía os sujeitos homossexuais, respondendo à (universal) injunção a interpretar a condição de silenciamento que os determinava: a guetização. Ao falar a respeito do discurso-origem - no caso, o discurso totalitário do regime militar de perfil castrador, no que concerne às sexualidades heréticas - o discurso sobre a censura moral atuou na institucionalização dos sentidos, da memória, contribuindo, inclusive, no rearranjo de seus trajetos ${ }^{27}$.

"Saindo do gueto" é o enunciado que intitula o editorial da edição teste do Lampião, datada de 1978. O texto se lineariza em torno do objetivo de constituir o periódico como um espaço de enunciação dos homossexuais e que pudesse falar em favor desses sujeitos, havidos enquanto "minorias" que precisam ter voz; bem como desfazer a imagem-padrão que encamparia esses sujeitos. "Sair do gueto", então, pode significar a

\footnotetext{
${ }^{27}$ Consoante a definição proposta por Mariani (1996, f. 67), "Os discursos sobre são discursos que atuam na institucionalização dos sentidos, portanto, no efeito de linearidade e homogeneidade da memória. Os discursos sobre são discursos intermediários, pois ao falarem sobre um discurso de ('discurso-origem'), situam-se entre este e o interlocutor, qualquer que seja. De modo geral, representam lugares de autoridade em que se efetua algum tipo de transmissão de conhecimento, já que o falar sobre transita na correlação entre o narrar/descrever um acontecimento singular, estabelecendo sua relação com um campo de saberes já reconhecido peio interlocutor".
} 
contestação do silenciamento que decorria do discurso censório da ditadura militar, bem como que atuou na constituição da identidade do sujeito homossexual, sob a forma de um estigma universalizante, o se. Seja no título do editorial, seja dos demais elementos de efeito interior (intradiscurso), o sentido de gueto, não é expressamente definido em nenhum dos momentos do editorial. Ele é tomado como evidente, aparece como já-lá, pelo efeito de pré-construído. A partir trabalho do interdiscurso, são retomados, assim, sentidos gestados em outro lugar e independentemente. Uma voz sem nome se antepõe; a memória do dizer intervém para constituir sentidos. Pela remissão ao mnemônico, os sujeitos interpretam o gueto homossexual enquanto imagem do silêncio, sentido que alude, sobretudo, ao gueto judaico. Os recortes a seguir apresentados, extraídos da página três em que consta o editorial, permitem compreender de que maneira os sujeitos do discurso lidam com a evidência de gueto, isto é, enquanto imagem de silêncio, articulando dizeres, intrincados em formações imaginárias sobre si e sobre o silenciamento, em seus gestos de interpretação. Propomos, como questão de análise: como o si dos sujeitos homossexuais é falado no editorial em relação ao gueto e como esse dizer constitui vestígios de resistência à censura moral imposta pela língua-de-espuma da ditadura militar?

a. Brasil, março de 1978. Ventos favoráveis sopram no rumo de uma certa liberalização do quadro nacional $[. .$.$] ; [...] uma investigação das$ alternativas propostas faz até com que se fareje uma "abertura" do discurso brasileiro. Mas um jornal homossexual, para quê?

Em $a$, responde-se ao discurso de abertura política que circula durante o governo Geisel. A "abertura discursiva" a que se alude, sob suspensão aspeada, contracena com a pergunta sobre o que justificaria a criação e circulação de um periódico homossexual no Brasil. Pressupõe-se, então, que o período antecedente a 1978 expressaria um discurso "fechado". A pergunta que se coloca é: qual o sentido dessa abertura? Como ela significa? Se há, de fato, uma abertura discursiva, essa é, então, a condição de possibilidade de saída do gueto? Em "abertura discursiva", compreendemos o gesto de aspeamento enquanto sintoma da forma como os sujeitos do discurso tentam administrar a falta do dizer, pelo dizer da falta, constituindo pacto metaenunciativo com a fissura da linguagem na formulação, pelo que o sentido de "abertura" paira em suspensão, por efeito de uma suspeita. A não-justeza na nomeação aponta para a textualização da falta, que contamina o dizível historicamente possível pela interdição, isto é, pelo funcionamento censório da língua totalitária do regime militar. Trata-se, ao revés, de uma abertura gestada pela (auto)censura e regulada pelo poder, razão pelo que não se deve supor que o discurso 
aponte para um escancaramento semântico, onde o sentido possa ser qualquer um. Antes, o que se delineia, como efeito da relação material de interlocução que se estabelece em $a$, é "uma certa liberalização", que faz "com que se fareje uma abertura", mas não qualquer liberalização, tampouco qualquer abertura. Comparece, para os sujeitos do discurso, a necessidade de um jornal homossexual justamente pelo fato de a dita abertura não ser, e não significar, qualquer uma, estando afeita a (sobre)determinações que dividem, pelo político, a constituição de seu sentido. Algo não se inscreve "no aberto" do discurso, no dizível sócio-histórico, pela ocasião do silêncio-local. Entretanto, esse "algo" funciona na constituição do dizer que se põe em circulação com o periódico; por ele "respira", significa.

b. A resposta mais fácil é aquela que nos mostrará empunhando uma bandeira exótica ou "compreensível", cavando mais fundo as muralhas do gueto, endossando - ao "assumir" - a posição isolada que a Grande Consciência Homossexual reservou aos que não rezam pela sua cartilha, e que convém à sua perpetuação e ao seu funcionamento.

c. Nossa resposta, no entanto, é esta: é preciso dizer não ao gueto e, em consequência, sair dele.

d. O que nos interessa é destruir a imagem-padrão que se faz do homossexual [...].

Para que um jornal homossexual? Em $b$, os sujeitos do discurso procuram se afastar do que seria a imagem-padrão de homossexual $(d)$, ou, como compreendemos, expõem a imagem que fazem da imagem que o outro faz deles, para negá-la a partir da imagem que fazem de seu si, isto é, do real de suas condições de existência: um homossexual que empunha "uma bandeira exótica" é um homossexual que cumpre o estigma, submete-se à imagem-padrão. Em termos de formações imaginárias, "a resposta mais fácil" para o porquê de um periódico de notação cultural homossexual, implica “endossar" a condição de silêncio a que os sujeitos homossexuais estariam submetidos pelo gueto, isto é, "cavar mais fundo as suas muralhas"; ou ainda, identificar-se com o que seria "a Grande Consciência Homossexual", submetendo-se ao espaço de apagamento do si pelo se, a partir de uma "boa" tomada de posição subjetiva com relação ao discurso de assunção identitária - uma identidade compromissada ideologicamente com o funcionamento censório da língua totalitária do regime militar, que movimenta a trama e a ruína do eu, "perpetuando o seu funcionamento" silenciador. O que se coloca, entretanto, é um movimento de resistência ao funcionamento do censório, a partir de uma tentativa de escapar ao tecido imaginário que, pela ideologia, justapõe-se ao sentido de 
gueto para significar o sujeito homossexual pelo estigma, como se nota em $c$. Um jornal homossexual para quê? Para negar o gueto e formar as condições de possibilidade de saída dele, sendo uma delas, a destruição da suposta imagem-padrão que significa esses sujeitos pela sua inscrição numa Identidade compromissada com o funcionamento censório da língua do regime militar, já que expressa, materialmente, a aniquilação do si. Vemos, a seguir, em $e, f, g$ e $h$, os sentidos possíveis da aludia inscrição subjetiva, os quais trabalham, pelo político, o efeito-sentido de gueto na dinâmica material de interlocução que se estabelece no material de análise:
e. [...] ser que vive nas sombras $[\ldots]$
f. [...] encara a sua preferência sexual como uma espécie de maldição $[\ldots]$.
g. [...] dado aos ademares [...].
h. [...] seu sexo não é aquele que deseja ter.

Pela imagem que fazem de si, os sujeitos do discurso negam eficácia aos sentidos de homossexual articulados em $e, f, g$ e $h$; sentidos que, conforme o ritual ideológico, comparecem, para seu imaginário, como que colados a "gueto". O gueto, trabalhado enquanto um espaço de aparente invisibilidade discursiva, alinha-se com o sentido de homossexual como um "ser que vive nas sombras", visto em $e$; mas que, também, ressente-se de sua "maldição" (f), o que convoca o discurso religioso para compor a imagem; que é "dado aos ademares" ( $g$ ), isto é, que possui um comportamento espalhafatoso ou histérico, dito como inerente ao feminino, já que "seu sexo" não seria aparentemente aquele que ele "deseja ter" $(h)$. Se contrapõem a esses sentidos, outros $(i$, $l, m, n$ e $o$ ) com os quais os sujeitos do discurso se identificam, em face de sua recusa ao gueto:

i. [...] os homossexuais são seres humanos e que, portanto, têm todo o direito de lutar por sua plena realização, enquanto tal.

j. [...] abaixo os guetos e o sistema (disfarçado) de párias.

k. Falando da discriminação, do medo, dos interditos ou do silêncio, vamos também soltar a fala da sexualidade no que ela tem de positivo e criador $[\ldots]$.

1. O homossexual recusa para si e para as demais minorias a pecha de casta, acima ou abaixo das camadas sociais [...].

m. [...] ele não quer viver em guetos, nem erguer bandeiras que o estigmatizem [...]. 
n. [...] ele não é um eleito nem um maldito [...].

o. [...] sua preferência sexual deve ser vista dentro do contexto psicossocial da humanidade como um dos muitos traços que um caráter pode ter $[\ldots]$.

p. [...] uma minoria $[\ldots]$ precisa de voz.

Para sua plena realização enquanto tal $(i)$, os sujeitos do discurso visualizam como imperativa a necessidade de sair do gueto, ou dos muitos guetos, isto é, de todo o "sistema de párias", cujo funcionamento, na formação social capitalista brasileira do período, ocorre disfarçadamente, isto é, sob dissimulação ideológica $(j)$. “Abaixo [...] o sistema [...] de párias" produz um efeito de insubmissão às políticas de subalternização de que lança mão o discurso censório do regime militar, o que também se pode notar em $l$, quando é dito que o homossexual rejeita "a pecha de casta". Entretanto, isso se dá a partir do atravessamento ideológico do discurso liberal e humanista nesse dizer: ser homossexual deve se colocar em sinonímia em relação a "ser humano, enquanto tal", isto é, como todo mundo é (se), decalcar a forma-sujeito-de-direito. Sair do silêncio imaginário do gueto, portanto, deve significar a assunção de uma posição-sujeito no todo complexo do (inter)discurso, sob um reformismo político, pois se dá a partir da linguagem do direito e do Estado capitalistas ( $i$ ): os sujeitos homossexuais devem ter todo o "direito de lutar por sua plena realização", luta que deve necessariamente acontecer dentro do jogo político capitalista, sob o funcionamento do rito ideológico que constitui a todos "pequenos" sujeitos-de-direito. Assim é que os sujeitos do discurso visualizam a tomada de voz pela minoria sexual $(p)$. Voz no interior do rito estatal, mas ainda sim uma voz possível e passível de identidade.

Em $k$, o falar sobre a "discriminação", "o medo", "os interditos" ou "o silêncio" aponta para o efeito-sentido de gueto, tal como ele é interpretado pelos sujeitos do discurso. Reforça-se, então, o imaginário de gueto como um espaço de silenciamento: o gueto pode ser lido, parafrasticamente, como um lugar de discriminação, de medo, de interdição e censura. Sentidos que são retomados de outro lugar, que fala antes e independentemente, cujo funcionamento é dissimulado no efeito "interior" de intradiscurso. É aqui que a memória de gueto intervém para constituir, para que o sentido de gueto faça sentido na história. Comparece o sentido de gueto como alternativa à expulsão do perverso, sentido que é gestado desde as práticas de guetização judaica e que (re)escritura as práticas de guetização afro-americanas na metrópole fordista durante a 
maior parte do século XX. A constante determinante dos sentidos de gueto é ainda "o risco da contaminação simbólica": dos cristãos, num primeiro momento, dos brancos norte-americanos ${ }^{28}$, num segundo momento, e dos "bons" sujeitos heterossexuais, num terceiro momento. Ora, o imaginário que modalizava os sentidos de judeu nos idos da Veneza do século XVI enquanto figuras hereges, sujas e sensualmente perigosas ressoa na forma como a língua do regime militar trabalha os sentidos de homossexual, a partir de um funcionamento capsular, silenciador, imposto por um Eu que, pretendendo-se "exterior", hostiliza e "in(f)terioriza" o seu interlocutor (Tu). O estigma, o limite, o confinamento e o encapsulamento, os quatro elementos caracterizadores do gueto segundo Wacquant (2004), presentificam-se nas práticas de guetização do sujeito homossexual na ditadura militar como figura noturna, sombria, amaldiçoada e moralmente subversiva, metaforizada no sentido de degenerescência. Mas, esse falar sobre também aponta para um discurso de si, dos sentidos de sexualidade com que os sujeitos homossexuais se identificam. É nessa direção que se pode compreender que falar, então, acerca da repressão local que o gueto representa admite a "soltura da sexualidade", naquilo que nela possa haver de "positivo e criador".

Retomamos, agora, nossa questão de análise: como o si dos sujeitos homossexuais é falado no editorial em relação ao gueto e como esse dizer constitui vestígios de resistência à censura moral imposta pela língua-de-espuma da ditadura militar? Identificamos que, nos gestos de interpretação sobre o silenciamento e sobre o si dos sujeitos homossexuais, a resistência se deu, sobretudo, pela via de uma disputa representativa no interior de formações imaginárias. Resistiu-se à imagem comum de homossexual, enquanto figura necessariamente noturna, amaldiçoada, descontente com o seu sexo, dado aos ademares etc. Resistiu-se, igualmente, ao silenciamento imposto pela língua totalitária do regime militar, a partir: da caracterização de gueto como espaço de medo, discriminação, silêncio ou ainda interdição, isto é, espaço de contenção da circulação dos sentidos subversivos de homossexual; pelo chamado, aos homossexuais, para que dele saíssem; pela negação do próprio gueto, enquanto locus identitário.

\footnotetext{
${ }^{28}$ Para um panorama das práticas de guetização judaica e afro-americana, v. Wacquant (2004).
} 


\section{Auscultar o vestígio}

E nunca falou mais palavra, com pessoa alguma. Nós, também, não falávamos mais nele. Só se pensava. Não, de nosso pai não se podia ter esquecimento; e, se, por um pouco, a gente fazia que esquecia, era só para se despertar de novo, de repente, com a memória, no passo de outros sobressaltos.

Guimarães Rosa

No segundo ato, analisamos, no editorial da edição experimental (1978) do Lampião, como que, através de um discurso sobre o gueto e sobre o si dos sujeitos homossexuais, articulado sob imagens, constituíram-se vestígios de resistência à censura moral que se intensificou quando da suposta abertura política no regime militar. Questões permanecem: que é vestígio? Como se dá sua escuta e, mais propriamente, como se pode tornar o silêncio visível? Essas são questões que podem orientar este terceiro ato de nosso teatro textual, que cumpre o escopo de realizar um objetivo muito mais teórico-conceitual, e mesmo especulativo, que propriamente analítico. Aqui, recorremos a Paul Ricoeur, para evocar a significância do vestígio (trace), e a Martin Heidegger, para propor o conceito de ausculta, em sua produtividade para o estudo do silêncio, além de nos valermos de outros gestos de teorização e especulação.

A língua, no que concerne à divisão do trabalho semântico, é, para nós, a primeira margem da significação. Ela, consoante Pêcheux (2014[1975]), é a base comum de processos discursivos heterogêneos, os quais, dizemos, estão encampados pela segunda margem (discurso). Nesse sentido, podemos compreender a leitura que faz Pêcheux da linguística saussuriana, a qual constitui um dos pontos do tripé - entremeando-se com o Materialismo Histórico e a Psicanálise - que possibilita a instauração do continente "discurso", a partir da reescritura do par langue/parole pelo par langue/discours - o que não implica testemunhar acerca de uma eventual sinonímia entre fala e discurso, frisamos. $\mathrm{O}$ discurso não corresponde à fala, primado enunciativo dos subjetivismos idealistas. $\mathrm{O}$ discurso é, ao revés, não-subjetivo, no sentido mesmo em que é ele que diz o sujeito, significa-o, dá-lhe a sua identidade ( $s e$ ), sua realidade, o seu sentido. É só pelo efeito de esquecimento ideológico que os sujeitos se põem como origem, como subjetividade transcendente à palavra. O território da língua é a materialidade do discurso, mas também é onde o ausente, o impossível, comparece, des-re-territorializa a Lettre. Trata-se da margem mesma, a terceira margem da significação, em nosso modo de pensar: o silêncio. Mas que rio é esse, que se compõe das três margens de que estamos a supor? É rio do esquecimento (Rio Lethe). Noutras palavras: a Ideologia. Dizer isso é também 
circunscrever o avesso do Verbo à determinação do ideológico. Seguimos com a metáfora.

Então [diz] Anchises: as almas, para as quais, pelo destino, outros corpos são necessários, bebem, junto à onda do letéio rio, as incúrias águas e o longo oblívio (VIRGILIO, Eneida, Livro 6, 713-715).

No excerto de Eneida, o sentido de Lethe $(\lambda \dot{\eta} \theta \eta)$ vale como ocultar. Para que as almas pudessem, assim, (re)encarnar, era necessário esquecer. Lethe enquanto ocultar também está presente nos gregos, sobretudo em se tratando do problema da verdade (alétheia/ád $\dot{\eta} \theta \varepsilon \imath \alpha)$. O prefixo de negação - $\dot{\alpha}$ confere à verdade o estatuto de aparecer, mostrar, manifestar em oposição ao ocultar. Em Heidegger, como observa Melo (2018), alétheia compreende tanto o sentido de mostrar quanto o de ocultar. A verdade é o dentro e o fora da caverna! Não é Luz, como quer o projeto das iluminuras (Aufklärung), ou ainda, a verdade - fundadora da República - desde Platão (ou de Parmênides?) que governa a nossa vontade de saber. Não se trata de adequação entre palavra e coisa, sujeito e objeto, corpo e alma, razão e mundo, ser e ente, mas é mesmo essa reunião, consanguinidade do escuro-claro. Cumpre salientar que Lethe, como ocultar, está, igualmente, na base da acepção dominante de ideologia, desde Napoleão. Ideologia, então, deixa de se definir enquanto “[...] estudo da formação espontânea das ideias a partir das diferentes faculdades mentais (vontade, juízo, pensamento, memória, etc.) e, em última instância, a partir do próprio cérebro [...]" (DUNKER, 2008, p. 185), para identificar-se ao ocultamento metafísico. E declarou Napoleão, em seu discurso ao Conselho de Estado em 1812: "Todas as desgraças que afligem nossa bela França devem ser atribuídas à ideologia, essa tenebrosa metafísica que, buscando com sutilezas as causas primeiras, quer fundar sobre suas bases a legislação dos povos, em vez de adaptar as leis ao conhecimento do coração humano e às lições da história." (CHAUÍ, 2004[1980], p. 10) (Grifo nosso). É essa acepção de Lethe enquanto ocultamento que acompanha Feuerbach, Marx e outros: o paradigma da distorção pela inversão.

Distanciando-se disso, Pêcheux (2014[1975]) conceberá, a partir de Althusser (1980[1971]), a Ideologia enquanto funcionamento; mecanismo que atua na linguagem constituindo evidências subjetivas por dissimulação. É essa a acepção que mais propriamente nos interessa para caracterizar a metáfora do rio a que aludimos, sobretudo no que se refere à problemática pecheutiana do esquecimento. Recuperado o sentido de Lethe enquanto esquecimento não-psicológico, pelo que o real da existência ( $s i$ ) não se oculta, mas é dissimulado por um tecido de evidências subjetivas (se) - a forma unitária 
(eficácia do imaginário) - podemos seguir com a metáfora das margens do rio. Língua, discurso e silêncio: são essas as três margens do Rio Lethe (Ideologia). O lugar da terceira margem, em Guimarães Rosa (1988), é também lugar do impossível, do silêncio. A significância do não dizer do pai que segue com a canoa de uma margem a outra está "posta" e não é resto insignificante, mas real que faz vestígio (trace) na significância no conto, o não-dizer que embaralha o ritual e descontinua o iter ideológico pela apraxia/afasia, pelo silêncio-de-si. De nossa parte, dizemos isto: entre a margem da língua e a margem do discurso, está o silêncio. Mas como experimentá-lo? É só pela teoria que compreendemos o impossível em sua impossibilidade mesma e ele, assim, pode aparecer como tal, enquanto vestígio (trace), que é e tem uma história, como nos diz Burke (1999, p. 2): “Há uma geografia, uma sociologia e uma história do silêncio.”. Pela história, alçada do discurso, buscamos a sua significância, isto é, como ele, o silêncio, faz vestígio. Dentre as muitas trilhas possíveis, elegemos a que nos propõe Ricoeur (2010[1983]).

O conceito de vestígio, como nos apresenta Ricoeur (2010[1983]), constitui-se como um novo conector entre as perspectivas sobre o tempo, que o pensamento especulativo teve o condão de dissociar. Para o autor, o aludido conceito é requisito de todas as produções da prática histórica. Em sua relação com o passado, a sua dinâmica se expressa pela passagem, ao passo que sua estática se constitui pela marcação. $\mathrm{O}$ vestígio “[...] indica aqui, ou seja, no espaço, e agora, ou seja, no presente, a passagem passada dos vivos; ele orienta a caça, a busca, a pesquisa, a investigação.” (p. 204). Por essa razão, ele constitui um efeito-signo, já que combina uma relação de significância - é sinal de uma passagem - a uma relação de causalidade - é efeito de uma marcação adveniente do trabalho simbólico humano.

[...] por um lado, seguir um vestígio é raciocinar em termos de causalidade ao longo da cadeia de operações constitutivas da ação de passar por ali; por outro lado, remontar da marca à coisa que marca é isolar, entre todas as cadeias causais possíveis, aquelas que, além disso, veiculam a significância própria da relação entre o sinal e a passagem (p. 205).

O vestígio, então, em sua dupla vinculação (significância/marcação), alia o tempo do calendário, cotidiano e datável, ao tempo astral, em que marca a passagem, enquanto resto do passado, sendo dotado de historialidade derivada em relação àquele que produz a marca. Ele realiza uma sobreposição mútua entre tais perspectivas sobre o tempo, ao modo de uma troca fronteiriça, suturando a linha de fratura entre as figuras do tempo. Segui-lo é contar com o tempo; decifrar, no espaço, o estiramento do tempo, tendo em 
conta que, embora ele seja visível a todos, só é decifrável por alguns, como resultado de uma atitude científica abnegada, dotada de desapego. Apreender a significância do vestígio, portanto, exige remir o sinal à passagem. Para Ricoeur (2010[1983]), o que distinguirá o efeito-signo vestígio dos demais signos será o fato de ele perturbar a ordem da significação, ou, nas palavras de Lévinas, cf. citado por aquele autor, por ser a expressão da própria perturbação em seu acontecer. É assim que se pode conceber que um vestígio deixado por alguma caça perturba a ordem vegetal da floresta. Há que se supor, portanto, uma irretidão na correlação significado-significância quanto ao modo de ser do vestígio, isto é, uma estranheza, que decorre de ele não ser um signo igual a qualquer outro, já que ele não indica uma suposta presença, mas uma passagem; significa sem intenção qualquer de fazer signo, ou, ainda, pelo fato de ele significar sem fazer aparecer.

Ao propor uma apropriação teórica desse conceito, cf. as lentes da AD, para pensar a dinâmica e a estática da significância do silêncio, é oportuno, antes, compreender de que maneira o próprio dizer faz vestígio, para que então possamos nos interrogar a respeito de como pode o silêncio produzir uma marca. $\mathrm{O}$ discurso, efeito de sentido entre locutores, materialidade significante pelo mecanismo ideológico, pode, no movimento que propomos, ser havido enquanto o espaço do aqui, em que uma marca pode se produzir no agora. Enquanto materialidade, o discurso espacializa-se. Enquanto historicidade, impregnada de memória-esquecimento, o discurso é tempo. O seu efeito de evidência “interior" remete ao datável, ao cronológico, embora, no real, ele seja da ordem do astral. O discurso é, podemos dizer, efeito da passagem de um aspecto do tempo astral (interdiscurso), que produz uma marca datável num espaço significante (intradiscurso). Está cumprida a dupla vinculação do discurso, do dito, enquanto efeito-signo. Ele significa na dinâmica da interlocução e é causa dela, na medida em que ela se inscreve na ordem material do histórico para fazer sentido-Um no terreno da língua. Mas a trama do dizer só se realiza quando se pode supor alguma "retidão", seja enquanto estabilidade, paráfrase, identidade, gregarismo; seja enquanto "retificação", que se segue ao movimento de desestruturação-reestruturação das redes e trajetos de memória desencadeado por um acontecimento discursivo. Para sermos, então, de certa maneira, mais fiéis, ao fato de que o vestígio significa sem fazer aparecer, precisaremos lidar com o silêncio, matéria significante por excelência.

Ao compreendermos o tempo do silêncio, evocamos, novamente, a leitura de Orlandi (1997[1992]). O tempo do silêncio (aevum) é contínuo, enquanto que o tempo da 
palavra (tempus) é marcado. A palavra marca e segmenta o silêncio, constituindo um tempus no contínuo dos sentidos (aevum). Pensamos, assim, que o segundo aspecto do tempo astral - o primeiro fora lido como interdiscurso - é o silêncio fundante. A especificidade do vestígio do silêncio se torna, de certo modo, visível, ao supormos que o funcionamento do silêncio no discursivo contempla a ideia de irretidão, de perturbação que se exprime nas palavras. A dinâmica do silêncio é o contínuo do tempo (aevum), tempo astral; sua estática é a marcação, que culmina na palavra como rastro. E é o silêncio, portanto, que significa sem ambicionar ser signo como os outros. Por ele, impetra-se o vácuo no som, a disritmia na Identidade, a hiância, a aniquilação da alteridade possível sócio-historicamente, do dizer-outro, a dessignificação de sentidos não queridos. Sua sensibilidade não admite escuta, ouvido, captação. Entretanto, isso não implica a impossibilidade do impossível se fazer possível pela língua.

O simples ouvir se dispersa e destrói no que se pensa e se diz, no ouvir dizer, na doxa, na aparência. O auscultar autêntico, porém, não tem nada a ver com orelhas e palavreados, mas segue aquilo que o logos é: a unidade de reunião do ente em si mesmo. Ouvir verdadeiramente só podemos, quando já prestamos ouvidos, i. é, quando somos obedientes ao que ouvimos. Essa obediência, entretanto, nada tem a ver com os lóbulos auriculares. Quem não for obediente, estará, de antemão, igualmente distante e excluído do logos, por mais que possa ter ou não ter ouvido antes com as orelhas (HEIDEGGER, 1999[1953], p. 154).

Trabalhar (n)os limites da interpretação: é este o ofício do analista de discurso, aquilo que o diferencia do hermeneuta (ORLANDI, 2007[1999]). O analista, assim, não apenas interpreta, mas também descreve, de modo que o seu gesto de escuta de corpora não deve ambicionar univocidade, tampouco professar fé num real homogêneo do discurso, tal qual seria, para alguns, o real das ciências exatas (mas não para todos ${ }^{29}$ ). Mas como estabelecer uma escuta que acolha a opacidade da linguagem, a determinação dos sentidos pela história, a constituição do sujeito pela ideologia e pelo inconsciente, dando espaço para o acontecimento? Mais além. Como estabelecer uma escuta que seja igualmente sensível ao silêncio que permeia a linguagem, cortando as palavras? A escuta discursiva, sabemos, deve "ser obediente" a dois momentos de análise. Ela deve considerar que o sujeito falante interpreta e, assim, permitir descrever esse gesto, no que

\footnotetext{
$29 "[. .$.$] e se a palavra realidade não significa outra coisa senão o conjunto das conexões pelas quais nossa$ vida é amalgamada e suportada, então é com certeza verdadeiro que precisa haver regiões ou camadas da realidade muito diversas." (HEISENBERG, 2009, p.7). Embora o físico teórico alemão não trabalhe com a distinção entre real e realidade, acreditamos que sua proposta converge com a nossa, uma vez que questiona "a divisão tosca do mundo em uma realidade objetiva e uma realidade subjetiva." (idem, p. 135)
} 
nele possa haver de estabilizado, de gregário. Entretanto, não pode ser ingênua com relação ao próprio do analista, castrando-lhe a subjetividade pela suspensão (epoché) de seus juízos de interpretação. Não há descrição sem interpretação, embora aquela assuma uma certa primazia em AD (PÊCHEUX, 2015[1983]). O sujeito analista está "jogado no mundo da linguagem", estando sempre exposto ao real equívoco do ordinário do sentido. Aí atua o dispositivo teórico-analítico, de modo a permitir que o analista se (des)coloque no entremeio da descrição e da interpretação para contemplar o processo de produção de sentidos em suas condições materiais. Descrever a estrutura e interpretar o acontecimento. Esse é o imperativo que pressuriza a posição de analista, estabelecendo as condições de sua escuta discursiva. Mas, importa salientar, é porque há silêncio que pode haver acontecimento, razão pelo que aquele não pode ser objeto de foraclusão na leitura de corpora. "Esquecer" o silêncio pode implicar na construção de um ouvido inautêntico, retrocedendo ao dispositivo ideológico de interpretação. A sensibilidade do analista, então, poderá não apenas "ser obediente" ao já dito, e nesse sentido, construir a sua escuta, mas ela poderá admitir também certa "obediência" ao silêncio, indo além da escuta estritamente discursiva, sempre que os corpora assim o demandarem. É desde essa intuição que delineamos nosso gesto. Para sitiar o silêncio que corta o dito, então, pensamos ser oportuna, como um possível caminho analítico, a construção de uma "ausculta" atenta a essa materialidade significante, em sua especificidade, que se faça alternar com a escuta discursiva, na forma de um batimento. Escutar o dito e auscultar o silêncio, para, assim, ouvir o ser no ente, mas também o ser no próprio ser. Seguimos, então, esse duplo movimento, na individualização analítica do dispositivo teórico fornecido pela $\mathrm{AD}$, tendo, ainda, em conta que uma vez que o "[...] silêncio não está disponível à visibilidade, não é diretamente observável [...]” (ORLANDI, 1997[1992], p. 34), é possível se avizinhar dele havendo-o enquanto rastro, vestígio (trace); como aquilo que significa sem fazer aparecer.

\section{Referências}

ALTHUSSER, L. Ideologia e aparelhos ideológicos do Estado. Lisboa: Presença, 1980 [1971].

AUTHIER-REVUZ, J. Falta do dizer, dizer da falta: as palavras do silêncio. In: ORLANDI, E.P. Gestos de leitura: da história no discurso. Campinas, SP: Editora da Unicamp, 2010[1994].

BARTHES, R. Aula. São Paulo: Cultrix, 1978. 
BECK, M. A prática do calar como modo de subversão. In: Fabio Elias Verdiani Tfouni; Angela Derlise Stube; Clarice Pimentel Paulon. (Orgs.). Silêncio e interdito: discursos em movimento. São Carlos: Pedro e João, 2016, v. 1, p. 11-246.

BECK, M. Apraxia e silenciar: formas resistência-revolta por meio de uma subtração subjetiva. Revista Conexão Letras, v. 8, n. 10, 2013.

BECK, M. Aurora Mexicana - Processos de resistência-revolta-revolução em lutas populares da América Latina: o exemplo do discurso zapatista. 2010. 175 f. Tese (Doutorado em Letras) - UFSM, Santa Maria, 2010.

BRITO, A. O Lampião da esquina: uma voz homossexual no Brasil em tempos de fúria (1978-1981). Dissertação (Mestrado em História) - Universidade de Brasília, 2016.

BURKE, P. Escutar o silêncio. Folha de S. Paulo, v. 19, p. 4, 1999.

CHAUÍ, M. O Que é ideologia. São Paulo: Brasiliense, 2004[1980].

COWAN, B. Homossexualidade, ideologia e subversão no regime militar. In: QUINALHA, R.; GREEN, J. (Orgs). Ditadura e homossexualidades: repressão, resistência e a busca de verdade. São Carlos: EDUFscar, 2015.

DUCROT, O. Implícito e pressuposição. In: Linguística: dizer e não dizer. São Paulo: Cultrix, $1 \overline{977 .}$

Princípios de Semântica

DUNKER, C. I. L. Discurso e Ideologia. In: SIGNORINI, Inês (Org.). [Re]discutir texto, gênero e discurso. São Paulo: Parábola Editorial, 2008, p.185-213.

FICO, Carlos. Prefácio. In: QUINALHA, Renan; GREEN, James (Orgs). Ditadura e homossexualidades: repressão, resistência e a busca de verdade. São Carlos: EDUFscar, 2015.

FOGEL, G. Escuta, silêncio, linguagem. Aufklärung: revista de filosofia, v. 4, p. 47-58, 2017.

FOUCAULT, M. As palavras e as coisas: uma arqueologia das ciências humanas. São Paulo: Martins Fontes, 2002.

FOUCAULT, M. História da sexualidade: a vontade de saber. Rio de Janeiro: Paz e Terra, 2017[1976].

FOUCAULT, M. História da sexualidade: o cuidado de si. Rio de Janeiro: Paz e Terra, 2017[1984].

GUIMARÃES, E. Aquele que diz o que não diz. Uma biobliografia de Oswald Ducrot. Entremeios, v. 11, p. 167-178, 2015.

HAROCHE, C.; PÊCHEUX, M.; HENRY, P. A semântica e o corte saussuriano: língua, linguagem, discurso. Análise do discurso: apontamentos para uma história da noçãoconceito de formação discursiva. São Carlos: Pedro \& João, p. 13-32, 2007[1971].

HEIDEGGER, M. Carta sobre o humanismo. São Paulo: Centauro, 2005[1947].

HEIDEGGER, M. Introdução à Metafisica. Rio de Janeiro: Tempo Brasileiro, 1999[1953].

HEISENBERG, W. A Ordenação da Realidade. Tradução de Marco Antônio Casanova. Rio de Janeiro: Forense Universitária, 2009.

INDURSKY, F. A ideologia em Bakhtin e em Pêcheux: um estudo em contraponto. In: ZANDWAIS, A. (Org). Mikhail Bakhtin: contribuições para a filosofia da linguagem 
e estudos discursivos. Porto Alegre: Sagra Luzzatto, 2005. p. 101-115.

LAMPIÃO DA ESQUINA. Rio de Janeiro, nº 0, abr. 1978.

LISBOA, N. T. O silêncio como resistência à banalização da linguagem. In: Fabio Elias Verdiani Tfouni; Angela Derlise Stube; Clarice Pimentel Paulon. (Org.). Silêncio e interdito: discursos em movimento. São Carlos: Pedro e João, 2016, v. 1, p. 11-246.

MACRAE, E. A construção da igualdade: identidade sexual e política no Brasil da abertura. Campinas: Editora da Unicamp, 1990.

MARIANI, B. O comunismo imaginário: práticas discursivas da imprensa sobre o PCB (1922-1989). Tese (Doutorado em Linguística) - Instituto de estudos da linguagem, Universidade de Campinas. São Paulo, 256 f., 1996.

MELO, I.M. O fim do (jus)positivismo. Monografia (Curso em Direito). Universidade Estadual de Santa Cruz. Ilhéus, BA, 50 f., 2018.

ORLANDI, E. Alarido e silêncio. Revista linguagem, v. 3, p. 6-17, 2017.

ORLANDI, E. Análise de discurso: princípios e Procedimentos. Campinas: Pontes, 1999[2007].

ORLANDI, E. As formas do silêncio: no movimento dos sentidos. Campinas, SP: Editora da Unicamp, 1997[1992].

ORLANDI, E. Interpretação: autoria, leitura e efeitos do trabalho simbólico. Petrópolis, RJ: Vozes, 1996.

ORLANDI, E. Maio de 1968: os silêncios da memória. In: ACHARD, Pierre et al. Papel da memória. Campinas: Pontes, 1999. p. 59-71.

ORLANDI, E. P. N/O limiar da cidade. RUA, n. esp., p. 7-19, 1999.

ORLANDI, E. Segmentar ou recortar. Série estudos, v. 10, p. 9-16, 1984.

PÊCHEUX, M. \& FUCHS, C. A propósito da análise automática do discurso: atualização e perspectivas. In: Gadet, F \& HAK, T. Por Uma Análise Automática do Discurso Uma Introdução à Obra de Michel Pêcheux. Campinas. Ed Unicamp, 2a . edição. 1993[1975], p.163-252.

PÊCHEUX, M. A análise automática do discurso. In: GADET, Françoise; HAK, T. (Orgs.). Por uma análise automática do discurso: uma introdução à obra de Michel Pêcheux. Campinas, SP: Editora da Unicamp, 1997[1969]. p. 39-60. (Coleção Repertórios).

PÊCHEUX, M. O discurso: estrutura ou acontecimento? Campinas, SP: Pontes editores, 2015[1983].

PÊCHEUX, M. Ousar pensar e ousar se revoltar. Ideologia, marxismo, luta de classes. Décalages, v. 1, n. 4, p. 15, 2015[1984].

QUINALHA, R. Contra a moral e os bons costumes: a política sexual da ditadura brasileira (1964-1988). Tese (Doutorado em Relações Públicas) - Universidade de São Paulo, 2017.

RICOEUR, P. Tempo e narrativa: volume 3. São Paulo: WMF Martins Fontes, 2010[1983].

ROSA, J. G. A terceira margem do rio. Primeiras estórias, v. 14, p. 32-37, 1988.

SAUSSURE, F. de. Curso de linguística geral. São Paulo: Cultrix, 2012[1916]. 
SIMÕES JUNIOR, A. ... E havia um lampião na esquina: memórias, identidades e discurso homossexual no Brasil do fim da ditadura. (1978-1980). Dissertação (Mestrado em Memória Social) - Universidade Federal do Estado do Rio de Janeiro, 2006.

SIMÕES, J.; FRANÇA, I. Do gueto ao mercado. Homossexualismo em São Paulo e outros escritos. São Paulo, Editora Unesp, 2005.

TFOUNI, F. E. V. Interdito, silêncio e as modalidades da lógica aristotélica. In: Fabio Elias Verdiani Tfouni; Angela Derlise Stube; Clarice Pimentel Paulon. (Org.). Silêncio e interdito: discursos em movimento. São Carlos: Pedro e João, 2016, v. 1, p. 11-246.

VIRGILIO. Eneida. Buenos Aires: Losada, 2004.

WACQUANT, L. Que é gueto? Construindo um conceito sociológico. Revista de Sociologia e Política, n. 23, 2004.

Data de Recebimento: 29/01/2019

Data de Aprovação: 02/02/2019 


\section{Para citar essa obra:}

SANTOS, Iago Moura Melo dos; BECK Maurício Beck, Vestígios do silêncio. In: RUA [online]. Volume 25, número 1 - p. 137-164 - e-ISSN 2179-9911 - junho/2019. Consultada no Portal Labeurb - Revista do Laboratório de Estudos Urbanos do Núcleo de Desenvolvimento da Criatividade.

http://www.labeurb.unicamp.br/rua/

Capa: Detalhe da primeira capa do Lampião da Esquina. Rio de Janeiro, nº 0, abr. 1978. Disponível em: https://www.otempo.com.br/divers\%C3\%A3o/magazine/vanguardana-luta-por-direitos-1.550024

Laboratório de Estudos Urbanos - LABEURB

Núcleo de Desenvolvimento da Criatividade - NUDECRI

Universidade Estadual de Campinas - UNICAMP

http://www.labeurb.unicamp.br/

Endereço:

LABEURB - LABORATÓRIO DE ESTUDOS URBANOS

UNICAMP/COCEN / NUDECRI

CAIXA POSTAL 6166

Campinas/SP - Brasil

CEP 13083-892

Fone/ Fax: (19) 3521-7900

Contato: http://www.labeurb.unicamp.br/contato 